\title{
Growth Promoting Substances and Mineral Elements in Desiccated Coconut Mills (DC) Coconut Water
}

\author{
S. Umesha* and B. Narayanaswamy \\ Department of Agricultural Microbiology, UAS, GKVK, Bangalore, India \\ *Corresponding author
}

\section{Keywords}

Coconut Water, Residual Coconut Water, Cytokinin, Auxin and Mineral Elements.

\section{Article Info}

Accepted:

18 March 2016

Available Online:

10 April 2016

\author{
A B S T R A C T
}

Coconut water is one of the versatile and organically rich natural products in the coconut growing countries. This refreshing beverage is gain importance and increasing scientific evidence that supports the role of coconut water in health and medicinal applications. Coconut water is traditionally used as a growth supplement in plant tissue culture/micropropagation. The wide applications of coconut water can be justified by its unique chemical composition of sugars, vitamins, minerals, amino acids and phytohormones. The attempts made to evaluate the chemical composition of coconut water obtained from desiccated industries. Here, eight to nine months broken coconuts were used in the processing of DC powders, the coconut water as a waste product and left as it is into ponds or lakes. This organically rich coconut water was collected at two different stage - one is at breaking point (purely coconut water), second is at end point of processing (residual coconut milk $=$ coconut water + water) and conducted a bioassay test viz., cucumber cotyledon expansion test (cytokinin) and wheat coleoptiles test (auxin) for growth promoting substance and also major and micro nutrients were studied. The result showed that the fresh weight and cotyledon expansion area of cucumber were recorded highest in concentrated coconut milk $(0.663 \mathrm{~g})$ and $\left(1.83 \mathrm{~cm}^{2}\right)$ as compare to control $(0.305 \mathrm{~g})$ and $\left(0.90 \mathrm{~cm}^{2}\right)$. The highest coleoptiles length was recorded $(11.63 \mathrm{~cm})$ in 1:7 dilution (coconut water: water) as compare to residual coconut milk $(9.93 \mathrm{~cm})$ and control $(4.87 \mathrm{~cm})$. The mineral concentration of coconut water and residual coconut milk lies between $\mathrm{N}(0.63$ and $0.73 \%), \mathrm{P}(0.36$ and $0.23 \%), \mathrm{K}(2.36$ and $2.56 \%), \mathrm{Ca}(1.64$ and $1.20 \%), \mathrm{Na}(0.48$ and $0.41 \%)$ and micronutrients viz., Fe (93.2 and $91.6 \mathrm{ppm}), \mathrm{Cu}(17.4$ and $17.8 \mathrm{ppm}) \mathrm{Zn} \mathrm{(20.6} \mathrm{and}$ $22.6 \mathrm{ppm})$ and $\mathrm{Mn}$ (84.0 and $76.2 \mathrm{ppm})$ were recorded respectively.

\section{Introduction}

Coconut water is traditionally used as a growth supplement in plant tissue culture/micropropagation and best medium for microbial growth. The wide applications of coconut water can be justified by its unique chemical composition of sugars, vitamins, minerals, amino acids and phytohormones. Coconut water as a waste product in Desiccated coconut industries after processing of the desiccated coconut 
powder. This water is organically rich nutrients and growth promoting substances.

Desiccated coconut (DC) is a dried white, particulate or shredded product manufactured from freshly peeled coconut kernel, produced in many sizes and textures from extra fine to course grades. It is available in various specialties or fancy-cuts like chips, threads, flakes and slices. About $60 \%$ to $80 \%$ of global DC production is used in the bakery and confectionery industries to enhance the texture, flavor, aroma, degree of chewiness and appearance of a wide variety of food products like nut bars, cookies, biscuits, cakes, pies, and ice cream.

The desiccated industries produces lot of waste water during the processing, an average different types of water comes from desiccated mills with a production output of $1000 \mathrm{Kg} /$ day, it releases 1500 to 2000 liters of coconut water and 800 to 1000 liters of pasteurized water. This large volume of highly organic 'waste water' is a major pollution problem in any desiccated coconut processing plant before implementing the recovery of byproducts of crude coconut oil and copra meal. Based on these themes we are utilizing and known the nutrients and growth hormones in the organically rich coconut water obtained from DC industry.

\section{Materials and Methods}

\section{Source of Desiccated Coconut Water (DC Water)}

The eight to nine months old broken coconuts water was collected from Maruthi desiccated coconut mills at Kaidal gate, Tiptur taluk, Tumkur district. The desiccated coconut water was collected at two different stages,

1. Coconut water- this water is collected at the time of breaking. It contains only pure coconut water.

2. Residual coconut milk - this was collected after preparation desiccated coconut powder. This milk containsCoconut water + water used for washing the de-shelled coconut pieces.

The fresh samples of coconut water and milk were collected in plastic containers and brought into the laboratory to study the Growth hormones and Nutrients analysis in these water samples.

\section{Bioassay Test for Cytokinins (Cucumber Cotyledon Expansion Test)}

Seeds of cucumber (Cucumis sativus $\mathrm{L}$ var. long white) were obtained from Keyonic seeds Ltd. Bangalore, Karnataka, India. Seeds were washed with tap water and finally with distilled water. Seeds were then spread moist filter paper in Petri dishes and incubated under dark at room temperature. Cotyledons were excised under sharp blade from seedlings grown for $48 \mathrm{hr}$ in dark. Cotyledons were excised from these seedlings and ten cotyledons were floated in Petri dishes possessing a $4 \mathrm{ml}$ of (a) Water (b) Coconut water (c) Residual coconut milk and were allowed to grow in dark for required time period. The experiment was run with triplicate set of cotyledons. The values were presented as mean of three replicates (Sunita et al., 2005).

\section{Bioassay Test for Auxins (Wheat Coleoptile Test)}

Seeds of Triticum aestivum (wheat) obtained from farmer of Gulbarga district Karnataka, India. Seeds were washed with tap water and finally with distilled water and germinated on plastic tray containing moist sand in dark at room temperature. After 2 days of 
germination, when the coleoptiles attain approximately $2-3 \mathrm{~cm}$ long were excised near their bases, drawn from the primary leaf and five coleoptiles sections floated in petridishes possessing a $10 \mathrm{ml}$ of (a) Water, (b) Coconut water and (c) Residual coconut milk and placed in dark. The experiment was run with triplicate set of coleoptiles. The values were presented as mean of three replicates (Fergus et al., 1977).

\section{Treatment details}

\begin{tabular}{|c|c|l|}
\hline Treatments & Ratio & \multicolumn{1}{|c|}{ Description } \\
\hline $\mathrm{T}_{1}$ & Control & Control \\
\hline $\mathrm{T}_{2}$ & 1 & $\begin{array}{l}\text { Concentrated coconut water } \\
\text { Concentrated residual milk }\end{array}$ \\
\hline $\mathrm{T}_{3}$ & $1: 1$ & $\begin{array}{l}\text { Coconut: Water } \\
\text { Residual coconut milk: Water }\end{array}$ \\
\hline $\mathrm{T}_{4}$ & $1: 2$ & $\begin{array}{l}\text { Coconut: Water } \\
\text { Residual coconut milk: Water }\end{array}$ \\
\hline $\mathrm{T}_{5}$ & $1: 3$ & $\begin{array}{l}\text { Coconut: Water } \\
\text { Residual coconut milk: Water }\end{array}$ \\
\hline $\mathrm{T}_{6}$ & $1: 4$ & $\begin{array}{l}\text { Coconut: Water } \\
\text { Residual coconut milk: Water }\end{array}$ \\
\hline $\mathrm{T}_{7}$ & $1: 5$ & $\begin{array}{l}\text { Coconut: Water } \\
\text { Residual coconut milk: Water }\end{array}$ \\
\hline
\end{tabular}

\section{Nutrient Analysis}

\section{Collection and Preparation of Desiccated Coconut Water Samples}

The desiccated coconut water was collected at two different points one is at breaking point (pure coconut water) and another at outlet (residual milk). The fresh samples of coconut water and milk were collected in plastic containers and brought into the laboratory for further analysis. All elements were determined under the plant sample analytical procedure.

\section{Nitrogen}

The nitrogen in DC water samples was determined by Kjeldahl's digestiondistillation method as described by Piper (1966). In this method $10 \mathrm{ml}$ of DC water sample was digested with conc. $\mathrm{H}_{2} \mathrm{SO}_{4}$ in presence of digestion mixture $\left(\mathrm{K}_{2} \mathrm{SO}_{4}: \mathrm{CuSO}_{4} .5 \mathrm{H}_{2} \mathrm{O}: \mathrm{Se}\right.$ in the proportion of 100:20:1) and distilled under alkaline medium. The liberated $\mathrm{NH}_{3}$ was trapped in boric acid containing mixed indicator and titrated against standard $\mathrm{H}_{2} \mathrm{SO}_{4}$.

\section{Digestion of Samples with Di-acid Mixture}

DC water sample of $10 \mathrm{ml}$ was pre-digested with $5 \mathrm{ml}$ of concentrated $\mathrm{HNO}_{3}$ and again digested with a di-acid mixture $\left(\mathrm{HNO}_{3}\right.$ : $\mathrm{HClO}_{4}$ in the proportion of 10:4 ratio). Volume of the digested sample was made up to $100 \mathrm{ml}$ with distilled water and preserved for $\mathrm{P}, \mathrm{K}, \mathrm{Ca}, \mathrm{Mg}, \mathrm{Na}, \mathrm{S}$ and micronutrients analysis.

\section{Phosphorus}

To a known volume of the di-acid digested extract, vanadomolybdate was added to develop yellow colour of vanadomolybdo phosphoric acid in nitric acid medium. The colour intensity was measured at $420 \mathrm{~nm}$ wavelength.

\section{Potassium}

The potassium content was estimated by atomizing the digested diluted sample to a calibrated flame photometer under suitable measuring conditions.

\section{Results and Discussion}

The fresh weight $(\mathrm{g})$ and expansion leaf area $\left(\mathrm{cm}^{2}\right)$ of cotyledons was showed highest in concentrated residual coconut milk as compare to control (Fig 1 and 2). The concentrated coconut water inhibited the expansion of cotyledons due to sensitivity of higher concentrations of cytokinins or chemical composition changes in coconut water from six to nine months coconut fruits 
have been reported (Siti et al., 2015 and Lazim et al., 2015) (plate.1). The lengths of coleoptiles $(\mathrm{cm})$ were recorded highest in the 1:7 (coconut water: water) dilution as compare to control (Fig 3 and plate 2). Based on these bioassay results, the Coconut water contains naturally occurring organic phytohormones viz., auxin and cytokinin. These are played a crucial role in regulating plant growth in a wide range of developmental processes (Reddy and Lakshmi, 2013)

Table.1 Methods Followed for the Analysis of Samples

\begin{tabular}{|l|l|l|}
\hline \multicolumn{1}{|c|}{ Parameters } & \multicolumn{1}{c|}{ Methods } & \multicolumn{1}{c|}{ References } \\
\hline Nitrogen (\%) & Kjeldahl digestion distillation method & Piper, 1966 \\
\hline Phosphorus (\%) & Diacid digestion and vanadomolybdate yellow method & Piper, 1966 \\
\hline Potassium and Sodium (\%) & Diacid digestion and Flame Photometer method & Piper, 1966 \\
\hline Calcium (\%) & Diacid digestion and Versenate titration method & Jackson, 1973 \\
\hline Magnesium (\%) & Diacid digestion and Versenate titration method & Jackson, 1973 \\
\hline Sulphur (\%) & Diacid digestion and Turbidometry method & Jackson, 1973 \\
\hline Fe, Mn, Zn and Cu (ppm) & $\begin{array}{l}\text { Diacid digestion and Atomic Absorption } \\
\text { Spectrophotometer method }\end{array}$ & Jackson, 1973 \\
\hline
\end{tabular}

Table.2 Mineral element concentration in DC coconut water

\begin{tabular}{|c|c|c|c|c|c|c|c|c|c|c|c|}
\hline Samples & $\begin{array}{c}\mathbf{N} \\
(\boldsymbol{\%})\end{array}$ & $\begin{array}{c}\mathbf{P} \\
(\boldsymbol{\%})\end{array}$ & $\begin{array}{c}\mathbf{K} \\
(\boldsymbol{\%})\end{array}$ & $\begin{array}{c}\mathbf{S} \\
(\boldsymbol{\%})\end{array}$ & $\begin{array}{c}\mathbf{N a} \\
(\boldsymbol{\%})\end{array}$ & $\begin{array}{c}\mathbf{C a} \\
(\boldsymbol{\%})\end{array}$ & $\begin{array}{c}\mathbf{M g} \\
(\boldsymbol{\%})\end{array}$ & $\begin{array}{c}\mathbf{Z n} \\
(\mathbf{p p m})\end{array}$ & $\begin{array}{c}\mathbf{C u} \\
(\mathbf{p p m})\end{array}$ & $\begin{array}{c}\mathbf{F e} \\
(\mathbf{p p m})\end{array}$ & $\begin{array}{c}\mathbf{M n} \\
(\mathbf{p p m})\end{array}$ \\
\hline $\begin{array}{c}\text { Coconut water } \\
\begin{array}{c}\text { Residual coconut } \\
\text { milk }\end{array}\end{array}$ & 0.62 & 0.36 & 2.36 & 1.64 & 0.86 & 0.1 & 0.48 & 20.6 & 17.4 & 93.2 & 84 \\
\hline
\end{tabular}

Fig.1 Fresh Weight of Cotyledons as Influenced by DC Industry Coconut Water

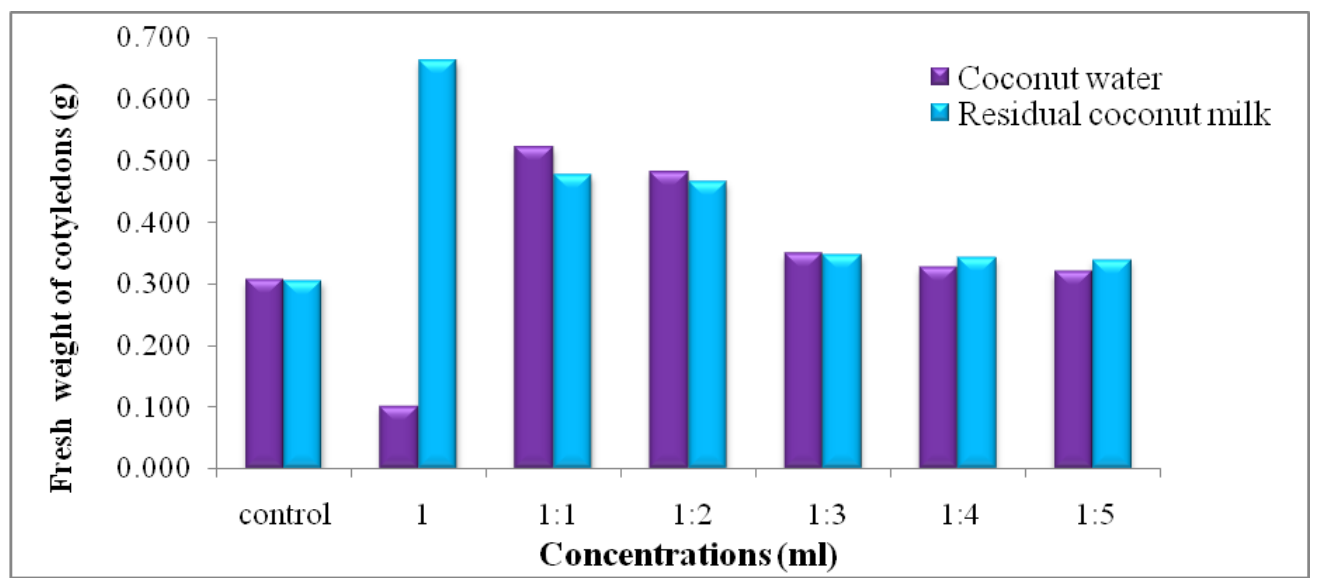


Fig.2 Leaf Area of Cotyledons as Influenced by DC Industry Coconut Water

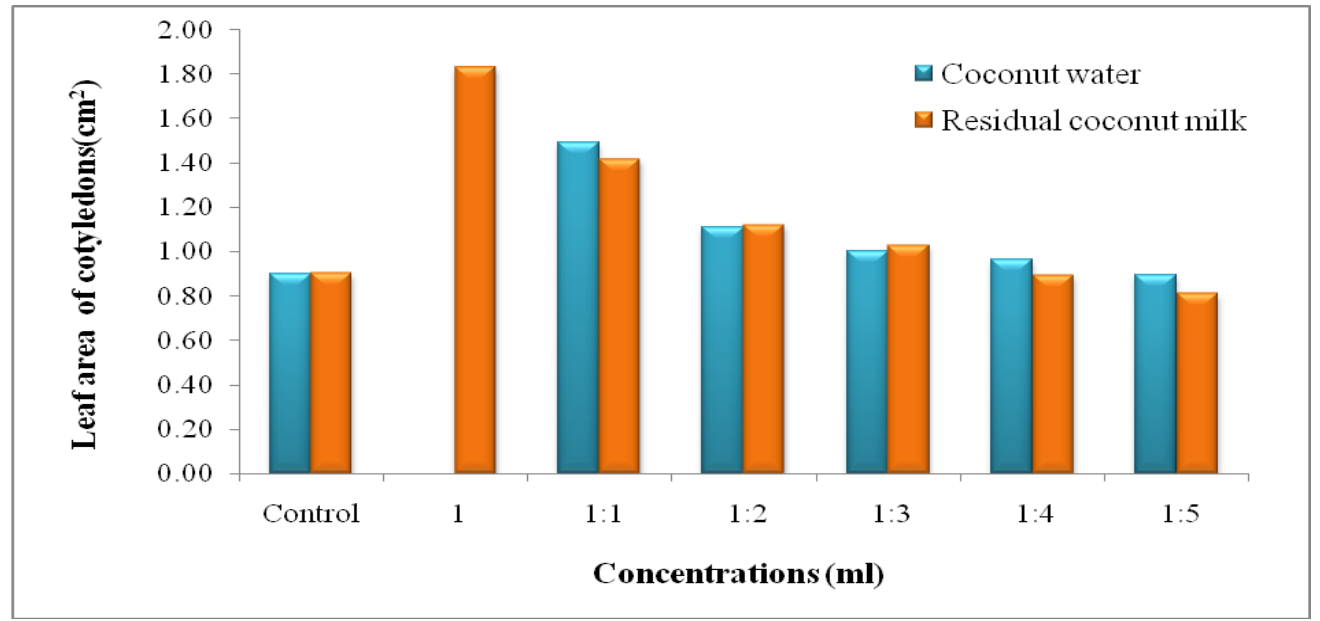

Plate.1 Cucumber Cotyledons Response to Cytokinin in DC Industry Coconut Water

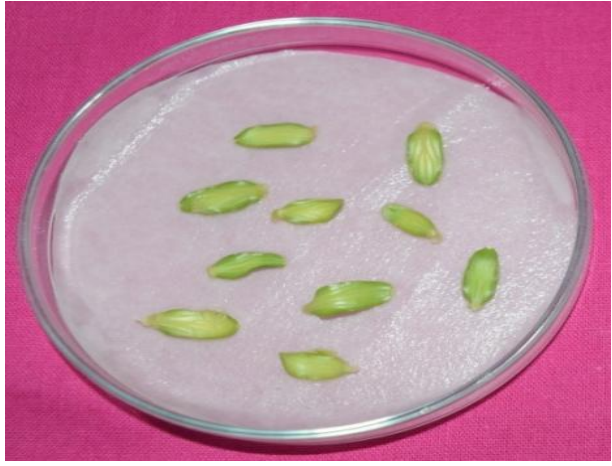

Control

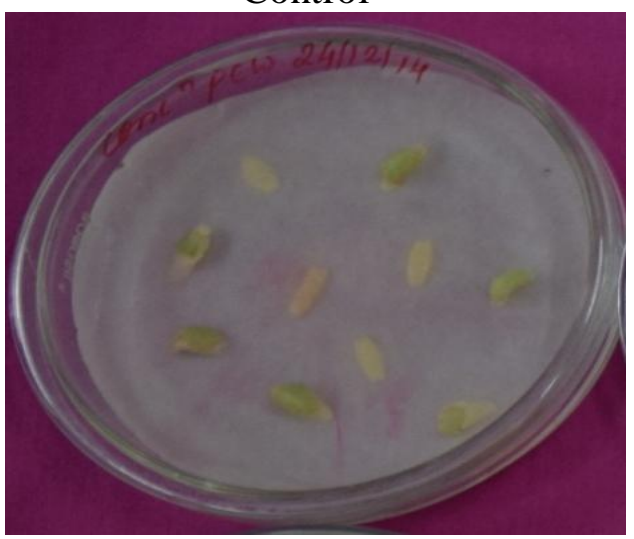

Concentrated coconut water

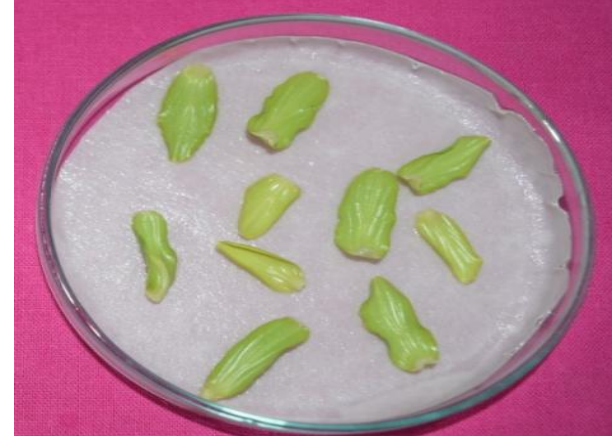

Concentrated residual milk

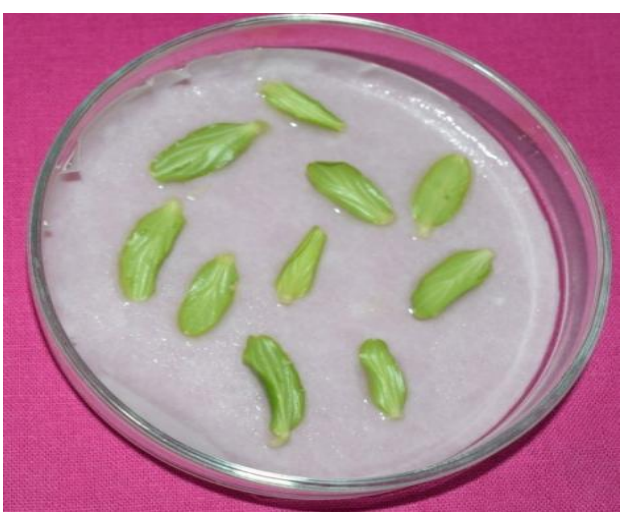

1:1 (Coconut water + water) 
Plate.2 Wheat Coleoptiles Response to Auxin in DC Industry Coconut Water

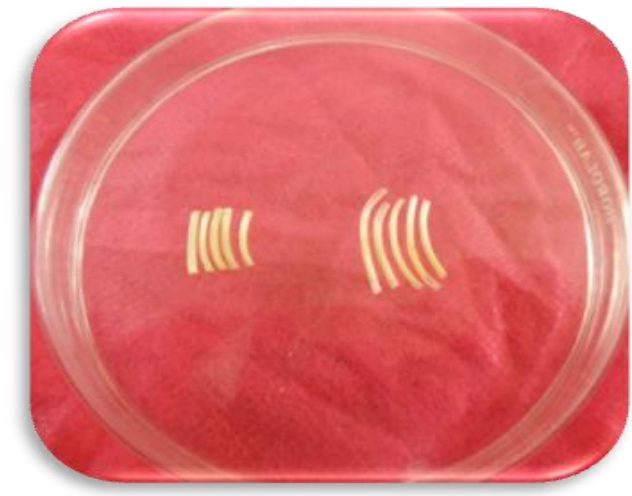

1:7 (Water + Coconut water)

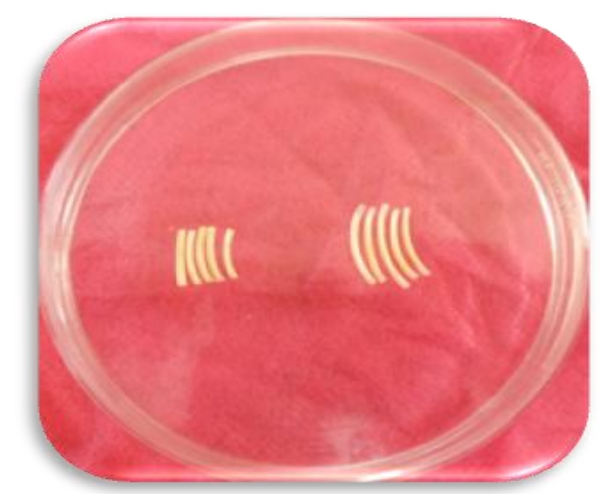

1:7 ( Water + Residual coconut milk)

Fig.3 Length of Coleoptiles as Influenced by DC Industry Coconut Water

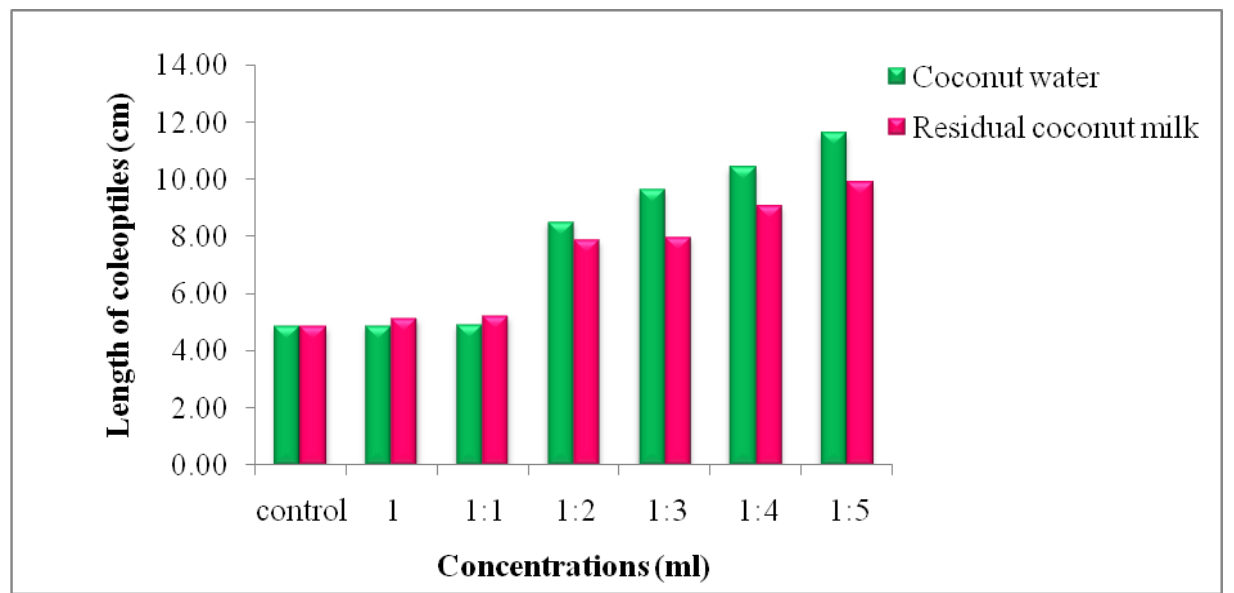

In the cause of determining the concentration of mineral element in coconut water obtained from desiccated coconut industry, the following tabulated results were obtained. Comparing the results obtained from the two different samples analyzed. It was also confirmed from the above results that a natural coconut posses some amount of all essential nutrients are present in coconut water presented in table 2 (Chuku and Kalagbor, 2014).

\section{Acknowledgement}

I would like to express our gratitude to my Advisory committee, all Staffs and friends in the Department of Agricultural
Microbiology, UAS, GKVK, Bangalore-65, for the technical support in this research. I thankful to Maruthi DC mill owner, Tiptur, Tumkur district, providing the DC industry water for my research work.

\section{References}

Chuku, L.C., Kalagbor, G.I. 2014. Protein and mineral element content of coconut (Cocos nucifera) water from different species. Ameri. J. Advan. Drug Deliv., 2(4): 451-453.

Fergus, D., Macdowall, H., Claude, S.J. 1977. Importance of time after excision and of $\mathrm{pH}$ on the kinetics of response of wheat coleoptile segments to added 
indoleacetic acid. Pl. Physiol., 59: 405410.

Jackson, M.L. 1973. Soil Chemical analysis. Prentice Hall of India (pvt.) Ltd., New Delhi.

Lazim, M.I.M., Nurul, A.B., Koh, S.P., Kamariah, L. 2015. Quantification of cytokinins in coconut water from different maturation stages of malaysia's coconut (Cocos nucifera L.) varieties. J. Food Process Technol., 6(11): 515.

Piper, C.S. 1966. Soil and Plant analysis.Hans Publishers, Bombay.

Reddy, P.E., Lakshmi, M.T. 2014. Coconut water - properties, uses, nutritional benefits in health and wealth and in health and disease: A Review. J. Curr. Trends in Clin. Med. Lab. Biochem., 2(2): 6-18.

Siti, M.S., Linda, M., Jansen, S. 2015. Analysis of total protein and non protein nitrogen in coconut water and meat (Cocos nucifera L.) by using kjeldahl method. Int. J. Pharm. Tech. Res., 8(4): 551-557.

Sunita, K., Karishma, J., Guruprasad, K.N. 2005. Involvement of oxyradicals in promotion/inhibition of expansion growth in cucumber cotyledons. Indian J. Experi. Bio., 43: 910-915.

\section{How to cite this article:}

Umesha, S., and Narayanaswamy, B. 2016. Growth Promoting Substances and Mineral Elements in Desiccated Coconut Mills (DC) Coconut Water. Int.J.Curr.Microbiol.App.Sci.5(4): 532-538. doi: http://dx.doi.org/10.20546/ijcmas.2016.504.060 